\title{
Description of Gestational Mellitus Diabetes in the General Hospital Dr. Zainoel Abidin Banda Aceh in 2018
}

\author{
Cut Meurah Yeni' ${ }^{1}$, Aldilo Talima ${ }^{2}$, Hijdrian Milzam² \\ ${ }^{1}$ Departement Obstetrics and Gynecology of RSUDZA, Faculty of Medicine, Universitas Syiah Kuala, \\ Banda Aceh, Indonesia \\ ${ }^{2}$ Faculty of Medicine, Universitas Syiah Kuala, Banda Aceh, Indonesia \\ cutyeni65@gmail.com
}

\begin{abstract}
Gestasional diabetes mellitus (GDM) is a glucose intolerance of variable severity with onset or first recognition during pregnancy. This is a silence occurred disease by the patient so it made much of morbidity for baby and the mother. Purpose of the research is to found the prevalence of GDM in RSUDZA and how was the delivery outcome in 2018. This is a descriptive research which use medical record as a secondary data. Sample of the research is all of pregnant woman who diagnosed with GDM and got treatment at RSUDZA in 2018. From the research we got from 2538 pregnant woman there are 55 of them was diagnosed with GDM. 15 of them (27,3\%) had a baby with birthweight >4000gr, and 6 of them (10,9\%) had a baby with birthweight $<2500 \mathrm{gr}$.
\end{abstract}

Keywords: diabetes mellitus; gestational; mother; baby

\section{Introduction}

Every health problem, generally caused by three factors that arise simultaneously, that are (1) the existence of other germs or disruptors,(2) the existence of an environment that allows the development of germs, and (3) the behavior of community not care about germs and the environment. Health and illness are largely determined by the human behavior. The behavior change problem is related to the effort of Health Promotion. Health Promotion is regulated in the Ministry of Health Regulation No. 1114 / Menkes / SK / VII / 2005 about Guidelines for Implementing Health Promotion in the Regions. Health Promotion is an effort to improve the abilityof the community through learning from, by, for and with the community, so that they can help themselves, and develop activities that are community-based, in accordance with local socio-cultural conditions and supported by public health-minded policies. (maswita, 2020)

Diabetes mellitus is a chronic metabolic disorder due to insulin deficiency or due to peripheral tissue resistance to insulin action. The path physiology involved is (1) decreased sensitivity of skeletal and hepatic muscle to insulin and (2) inadequate insulin secretion. Pregnancy is a state of chronic low-grade inflammation. This is associated with increased levels of circulating C-reactive protein (CRP) and Interleukin-6 (IL-6). Both of these factors trigger insulin resistance. The disorder lies in the secretion and action of insulin. The main effect is hyperglycemia. Based on the classification of diabetes divided into several types, including:
A. DM Type 1, characterized by the onset of young age (adolescents) and absolute insulinopenia. Has a genetic predisposition in the presence of auto antibodies.
B. Type 2 diabetes, characterized by the onset of old age, overweight women and insulin resistance in peripheral tissues (hyperinsulinemia).
C. DMG (Gestational Diabetes Mellitus)

And others: Genetic factors and drugs

Gestational Diabetes Mellitus is glucose intolerance that begins or is only discovered 
during pregnancy. It cannot be ruled out the possibility of unknown glucose intolerance that occurs with pregnancy. After the mother gives birth, the DMG will often return to normal glucose regulation.

Complications that may occur in pregnancy with diabetes vary greatly. In the mother will increase the risk of preeclampsia, cesarean section, and the occurrence of type 2 diabetes mellitus in the future, while the fetus increases the risk of macrodome, labor trauma, hyperalbuminemia, hypoglycemia, hypocalcemia, polycythaemia, neonatal hyperbilirubinemia, respiratory distress syndrome, and increase mortality, hyperalbuminemia, hypoglycemia, hypocalcaemia, polycythaemia, neonatal hyperbilirubinemia, respiratory distress syndrome, and increase mortality or fetal death.2

It is estimated that the global prevalence of diabetes mellitus will reach 380 million by 2025. This number represents $3.3 \%$ of all live births and $90 \%$ of them suffer from gestational diabetes mellitus. The increasing prevalence of type 2 diabetes, especially in younger populations, causes pregnancy with diabetes to increase as well.2

\section{Research Methods}

This research is a descriptive study with a cross sectional study design. The data collection was carried out on March 11-28, 2019. The population and sample in this study were all pregnant women with DMG diagnoses treated in obstetric care rooms and delivery rooms, RSUDZA in January 2018 to December 2018. With a total of 55 DMG patients who meet the inclusion criteria and do not meet the exclusion criteria. The research sample was selected by total sampling technique. The data obtained were analyzed statistically to determine the characteristics and prevalence of DMG.

\section{Discussion}

This study was conducted on 55 respondents who met the inclusion and exclusion criteria conducted in the obstetric ward and delivery room of the Banda Aceh Regional General Hospital.

Table 1. Characteristics of Respondents

\begin{tabular}{lc}
\hline $\begin{array}{c}\text { General } \\
\text { Characteristics }\end{array}$ & $\mathbf{n}(\boldsymbol{\%})$ \\
\hline Age (years) & $20(36,4)$ \\
$21-30$ & $31(56,3)$ \\
$31-40$ & $4(7,3)$ \\
$>40$ & \\
Baby's Weight & $6(10,9)$ \\
$\quad<2500$ gram & $34(61,8)$ \\
$2500-4000$ gram & $15(27,3)$ \\
$>4000$ gram & \\
Childbirth Method & $7(12,7)$ \\
$\quad \begin{array}{l}\text { Pervaginam } \\
\text { Section Caesarea }\end{array}$ & $48(87,3)$ \\
\hline
\end{tabular}

Based on Table 1, it was found that the average age of patients experiencing DMG was $32.85 \pm 5.02$ years. Based on the birth weight of babies 6 babies $(10.9 \%)$ have low birth weight (<2500gr), $34(61.8 \%)$ babies are born with moderate weight (2500-4000gr) and 15 (27.3\%) babies are born with excess body weight (> 4000gr). 
Based on the method of delivery $7(12.7 \%)$ study subjects underwent spontaneous termination of pregnancy, 48 (87.3.3\%) underwent section caesarean delivery.

Out of a total of 2,538 pregnant women treated in the Obstetric Treatment Room and the General Hospital of RSUDZA, 55 of them had gestational diabetes mellitus. This shows that the prevalence of mothers with gestational diabetes mellitus during pregnancy in RSUDZA during January-December 2018 reached $2.17 \%$.

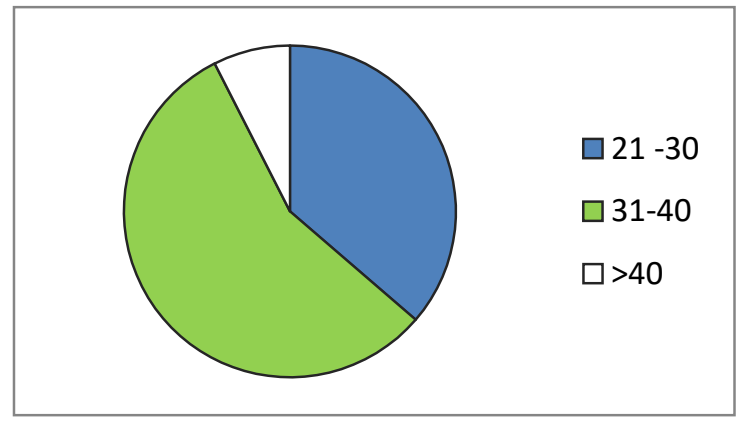

Diagram 1. Characteristics of Respondents by Age

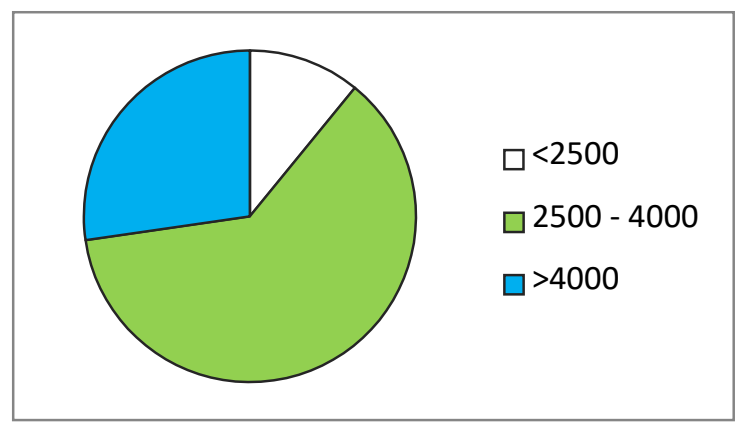

Diagram 2. Characteristics of Respondents by Birth Weight

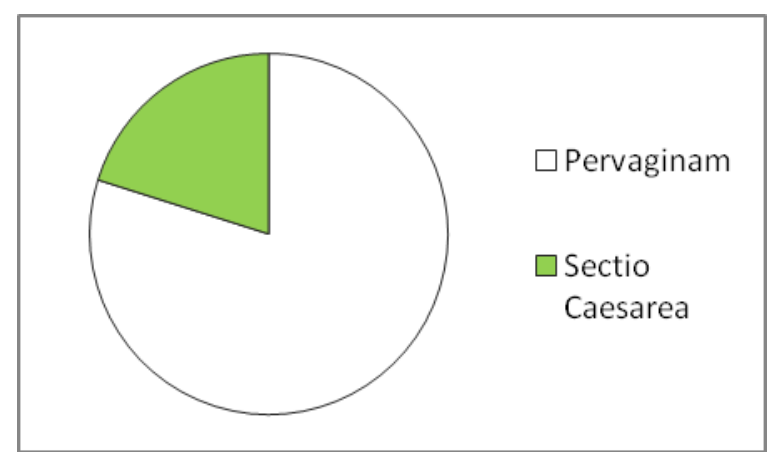

Diagram 3. Characteristics of Respondents Based on Childbirth Methods

This study shows that the prevalence of DMG in pregnant women in RSUDZA during January to December 2018 reached 2.17\%. This is in line with O'Sullvans's research in 2010 about the prevalence of DMG in Indonesia, which is as much as $1.9-3.6 \%$. In the United States, the prevalence of women with DMG is $2-5 \%$ between 2007 and 2014. This prevalence rate will continue to increase along with the increasing number of patients with diabetes mellitus. So that the need for increased supervision of pregnant women, and to urge every woman to carry out post-natal health checks. $(3,4,5,6)$ 
Maternal age is one factor that can contribute indirectly to the incidence of gestational diabetes mellitus. In this study, the most common DMG occurred at the age of 31-40 years. This is in line with Anita's research where the age range for susceptibility to DMG is during pregnancy at more than 30 years old. Other studies also mention that pregnant women aged $\geq 30$ years are 4.05 times more at risk for suffering from DMG compared to pregnant women with age $<30$ years. $(7,8)$

In this study, out of 55 DMG patients, 15 babies (27.3\%) were found in the category of macrosomia. This is caused by a condition where insulin function becomes not optimal. Changes in insulin kinetics and resistance to the effects of insulin, as a result of increased glucose content in maternal plasma, high blood sugar levels, but insulin levels remain high. Through facilitated diffusion in the placental membrane, where fetal circulation also occurs abnormal glucose content.

An increase in the level of serum metabolites in diabetic mothers (glucose, free fatty acids, ketone compounds in the body, triglycerides, and amino acids) will trigger an increase in the transfer of nutrients to the fetus which in turn will cause hyperglycemia in the uterine environment so that it can alter growth and fetal body composition.9 Increased glucose levels in pregnant women often cause adverse effects on the baby and the womb. Newborns from mothers with DM are usually larger (macrosomia), and there can also be enlargement of organs in the fetus such as the liver, adrenal glands and heart.

In this study 6 mothers had babies with birth weight <2500gr (10.9\%). Mothers with a long history of DM, trigger vascular vasciculopathy. As a result, uteroplacental insufficiency occurs which results in reduced nutrient transport from maternal to fetal. This will cause the fetus to experience hypoglycemia. So that the fetus will metabolize material other than glucose that is fat with the aim of meeting the needs of important organs. This will cause Intra-Uterine Growth Retriction (IUGR). 11,12

Shortly after birth, babies can experience hypoglycemia due to increased fetal insulin production, in reaction to high maternal glucose levels. Pregnant women with diabetes that are not well controlled will increase the risk of abortion and IUFD (intra uterine fetal death) .13

\section{Conclusion}

This study shows that among pregnant women in RSUDZA during January to December 2018 out of a total of 2,538 pregnant women who were treated in Arafah Room 3 RSUDZA, 55 of them had gestational diabetes mellitus. This shows that the prevalence of gestational diabetes mellitus during pregnancy in RSUDZA during January-December 2018 reached $2.17 \%$. The mean age of patients with DMG was $32.98 \pm 5.02$ years. In this study, out of 55 DMG patients, 15 babies $(27.3 \%)$ were found in the category of macrosomia.

\section{References}

Akbari S, Khodadadi B, Ahmadi SAY, Abbaszadeh S, Shahsavar F. Association of Vitamin D Level and Vitamin D Deficiency with Risk of Preeclampsia: A Systemic Review and Metaanalysis. Taiwanese Journal of Obstetrics and Gynecology. 2018; 57. P $241-47$.

Bilano VL, Ota E, Ganchimeg T, Mori R, Souza JP. Risk Factors Pre-eclampsia / Eclampsia and Its Adverse Outcome in Low and Middle Income Countries: A WHO Secondary Analysis. PlosOne. 2014; 9 (3). P 1 - 6.

Cunningham, FG et al. Williams Obstetrics 24th Edition. New York: Mc Graw Hill; 2014.

Dutta DC. 2015. Text Book of Obstetric. Philadelphia: Jaypee Medical Inc. P $258-60$. 
English FA, Kenny LC, McCarthy FP. Risk Factors and Effective Management of Preeclampsia. DovePress. 2015.

Kemenkes RI. Riset Kesehatan Dasar; 2013.

Maswita. (2020). The Role of Health Promotion on Smoke Free Area Implementation at Regional Work Unit Langsa City. ritain International of Exact Sciences (BIoEx) Journal. p. 298-303.

Prawiharjo, Sarwono. 2014. Ilmu Kebinanan. Jakarta: Bina Pustaka. P 213.

Roberge S, Bujold E, Nicolaides KH. Aspirin for Prevention of Preterm and Term Preeclampsia: Systemic Review and Metaanalysis. American Journal of Obstetrics and Gynecology. 2018

Sari NK, Hakimi M, Rahayujati TB. Determinan Gangguan Hipertensi Kehamilan di Indonesia. Berita Kedokteran Masyarakat. 2016; 32 (9). P 295 - 96.

Sherwood, L. 2014. Fisiologi Manusia: dari sel ke sistem. Edisi 8. Jakarta: EGC

Sperling JD, Dahlke JD, Huber WJ, Sibai BM. The Role of Headache in The Classification and Management of Hypertensive Disorders in Pregnancy. Obstet Gynecol. 2015; 126. P 297-302

The American College of Obstetricians and Gynecologists. 2013. Hypertension in Pregnancy. P $1-20$.

The American College of Obstetricians and Gynecologist. ACOG PRACTICE BULLETIN. Clinical Management Guidelines for Obstetrician-Gynecologist. 2019; 133 (1). 